\title{
Possible effects of COVID-19 on sustainability of aquatic ecosystems: An overview
}

\author{
Adams Ovie Iyiola ${ }^{1}$, Berchie Asiedu ${ }^{2}$, Femi John Fawole ${ }^{3} \mathbb{D}$
}

\section{Cite this article as:}

Iyiola, A.O., Asiedu, B., Fawole, F.J.. (2020). Possible effects of COVID-19 on sustainability of aquatic ecosystems: An overview. Aquatic Research, 3(4), 177-187. https://doi.org/10.3153/AR20016

${ }^{1}$ Osun State University, College of Agriculture, Department of Fisheries and Aquatic Resources Management, P.M.B. 4494, Osogbo, Osun state, Nigeria.

${ }^{2}$ Energy and Natural Resources University of, School of Natural Resources, Department of Fisheries and Water Resources, P.O. Box 214, Sunyani, Ghana.

${ }^{3}$ University of Ilorin, Department of Aquaculture and Fisheries, P.M.B. 1515, Ilorin, Nigeria.

ORCID IDs of the author(s): A.O.I. 0000-0002-2166-7299 B.A. 0000-0002-9879-718X F.J.F. 0000-0003-4645-6962

Submitted: 30.05 .2020

Revision requested 07.06 .2020

Last revision received 11.06.2020

Accepted: 11.06 .2020

Published online: 13.06 .2020

Correspondence: Adams Ovie IYIOLA E-mail: adams.iyiola@uniosun.edu.ng

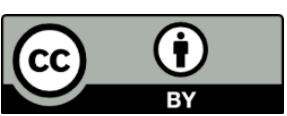

(C) 2020 The Author(s)

\section{Available online at}

http://aquatres.scientificwebjournals.com

\begin{abstract}
Coronavirus is an envelope virus that is persistent in the environment and easily inactivated by the use of chlorine disinfectants. It is a virus novel to human and the first occurrence (SARS-CoV) was detected in Hong Kong in 2003 and a new strain (SARS-CoV-2) in Wuhan, China in 2019. The pandemic had spread throughout the world and is spread through respiratory droplets and fecal-oral routes. The use of chlorine disinfectants has been reported to be the best economic solution to the virus and its use has been on the rise leading to increased wastewater generation. Presently, the existence of coronavirus has been reported in wastewater from indoor and outdoor sources and exposure of the aquatic ecosystem to this elevated concentration of chlorine in wastewater can threaten its sustainability and biodiversity. When aerosols or leakages occur from the sources of wastewater, humans can be infected by the virus by inhaling through the respiratory outlets. This review, therefore, highlights the possible presence and effect of the virus in waste water-based and how the aquatic environment can be sustained.
\end{abstract}

Keywords: Wastewater, Disinfectants, Sustainability, Aquatic environment, COVID-19 


\section{Introduction}

Ever since the first case of the strain of the coronavirus (COVID-19 also known as novel coronavirus) in Wuhan, Hubei Province in China, it has increasingly spread across the world at an alarming rate. The World Health Organization (WHO) has declared the virus as a Public Health Emergency of International Concern (Adhikari et al. 2020; WHO, 2020a). As of 17th May, 2020 WHO reported that COVID19 has spread over 216 countries of the world with a total of 4534731 confirmed cases and 307537 deaths. Americas top the list of cases both by WHO regions and by country, territory or area with 1966932 confirmed cases (Table 1) and 1409452 confirmed cases (Table 2) (WHO, 2020b). Severe acute respiratory syndrome coronavirus (SARS-CoV) is the strain that causes respiratory illness and is a highly pathogenic strain that was first identified in the mid-1960s. It is an enveloped single-stranded RNA virus that can infect birds, mammals, and humans through aerosols or fecal-oral route (Gundy et al. 2009).

Table 1. Case comparison of COVID-19 across WHO regions (WHO, 2020b)

\begin{tabular}{ll}
\hline WHO Regions & Confirmed cases \\
\hline Americas & 1966932 \\
Europe & 1870545 \\
Eastern Mediterranean & 335088 \\
Western Pacific & 167755 \\
South-East Asia & 135036 \\
Africa & 58663 \\
\hline
\end{tabular}

Table 2. Case comparison of COVID-19 by Country, Territory, or Area (WHO, 2020b)

\begin{tabular}{ll}
\hline Country, Territory or Area & Confirmed cases \\
\hline United States of America & 1409452 \\
Russian Federation & 281752 \\
The United Kingdom & 240165 \\
Spain & 230698 \\
Italy & 224760 \\
Brazil & 218233 \\
Germany & 174355 \\
Turkey & 148067 \\
France & 140008 \\
Iran & 120198 \\
India & 90927 \\
Peru & 84495 \\
\hline
\end{tabular}

The SARS-CoV was first discovered to have links with wastewater in March 2003 when an outbreak occurred in a housing estate in Hong Kong which involved over 300 people and caused over 8000 infection cases and mortality rate of 10\% (Centre for Disease Control, 2004). The outbreak was traced to a faulty sewage system (Peiris et al. 2003). An outbreak also occurred in 2004 from a research laboratory in Beijing, China, and was traced to bats because it was novel to humans at that time and spread through respiratory droplets (Manocha et al. 2003). At this time, a new strain of coronavirus known as SARS-COV-2 has been reported to the crossspecies barrier and can be transmitted through respiratory droplets over a short distance to humans by binding to the receptor angiotensin-converting enzyme 2 (ACE2) (Letko et al. 2020; Hoffman et al. 2020), through the environment, fecal-oral routes and wastewater systems (Zhang et al., 2020a).

Before $17^{\text {th }}$ March 2020, it was believed that the coronavirus was less stable in the environment and can easily be oxidized by chlorine; therefore, the virus can be rendered inactive by simple filtration and disinfection of wastewater (Aquatech, 2020). As of $12^{\text {th }}$ April 2020, traces of the virus were reported to be detected in wastewaters in the USA, Netherlands, and Sweden (Igomu, 2020). The virus was also being reported to be found in the fecal samples of infected individuals (Holshue et al. 2020). As a result, the use of chlorine disinfectant on indoor and outdoor surfaces has drastically increased. If this persists, a worldwide secondary disaster in aquatic ecosystems can occur which will threaten the existence of biodiversity (Zhang et al. 2020a) as ecosystem productivity. Presently, there has not been any report on the transmission of the virus from humans to land and aquatic animals (Goldstein, 2020) or from wastewater to aquatic animals but the effects of chlorine toxicity on the water quality and fish species have been reported (Sanders, 2020). Chlorine is a major constituent of disinfectants. Its toxicity can affect the sustainability of the aquatic ecosystem causing hypoxia, affecting organs and respiratory system, hepatic and renal injury, inflammation and steatosis (Xu et al. 2020; Rismanbaf and Zarei, 2020), and could migrate to the aquatic biota by surface run-off if pandemic persists (Zhang et al. 2020b), thus harming the aquatic organism and aquaculture. Due to the increasing spread of the virus worldwide, it is important to understand the virus in the aquatic environment and effective measures by which the aquatic environment can be sustained.

\section{Coronavirus and Wastewater}

The concept of sustainability of aquatic systems takes cognizance of the fate of the coronavirus and how it can affect life in the aquatic system. The virus is present in wastewater and 
can remain active over some time in waters originating from hospitals, sewage and fecal discharge from individuals infected by the virus (Hung, 2003; Zhang et al. 2020a). The virus is very persistent in wastewaters and the duration in which the virus is viable in wastewater is not yet known. It is therefore a point of call to know the longevity of the virus once discharged into wastewater to preserve aquatic ecosystems (Leung et al. 2003). Based on the SARS-CoV pandemic in 2003 , it was reported that the virus can survive and multiply within a short period if disinfection is not done and can be contagious (Wigginton et al. 2015; Choudri and Charabi, 2019).

The survival of coronavirus in wastewater depends on the following factors:

i. Temperature: the virus is sensitive to temperature and can be inactive if the temperature of wastewater is above or below the survival range. For instance, it was reported that the virus (i.e. coronaviruses) is inactivated faster in fresh water at $23^{\circ} \mathrm{C}$ than in fresh water at $4^{\circ} \mathrm{C}$ (Gundy et al. 2009).

ii. Organic matter: the virus can absorb materials in the water thereby shielding light

iii. Exposure to light: the virus can be inactivated in water by exposure to solar or ultra-violet radiation

iv. The presence of antagonistic microbes in wastewater (Naddeo and Liu, 2020)

Based on the recurrent happenings of this aggressive virus; from the 2003 SARS-CoV case to the 2019 SARS-CoV-2 case in China, the need for more information into the potential transmission via environmental measures such as wastewater pathways is of great importance (Chattopadhyay and Taft, 2018). Specific monitoring programmes for the virus in water can be carried out and models developed to provide information on the potential activities of the coronavirus.

The 12 facts about COVID-19 in water (Figure 1) and the importance of water access and hygiene in times of crisis have been summarized as follows (Tu Delft, 2020):

1. Cultivation of COVID-19 virus from stool is difficult

Wölfel et al. (2020) observed a high concentration of COVID-19 virus in the stool of hospitalized patients with COVID-19 and reported that the virus can be readily isolated from the throat and lungs of patients but not from feces.
2. Genetic material of COVID-19 virus found in sewage water

The virus was first detected in sewage by Medema et al. (2020) when sewage samples from 7 cities and an airport were tested during the outbreak in the Netherlands. It was proposed that the virus can be monitored in a population using sensitive monitoring tool such as the use of sewage detection. The genetic material is only found in water if it is contaminated with sewage.

3. Poor survival of SARS-CoV-1 (very similar virus to COVID-19) in water $>20^{\circ} \mathrm{C}$ indicates inactivity of COVID-19 virus in water

The survival of coronavirus SARS-CoV-1 in feces, urine, and water at different temperatures were investigated by Wang et al. (2005). It was reported that the SARS-CoV-1 was inactivated faster in wastewater at $20^{\circ} \mathrm{C}$ ( 2 days) than at $4^{\circ} \mathrm{C}$ (14 days).

4. Other viruses, e.g. rotavirus, are more persistent in water than the COVID-19 virus

It was reported by Raphael et al. (1985) from their study on the loss of rotavirus in water that at $20^{\circ} \mathrm{C}$, it took about 10 days for the occurrence of a reduction in rotavirus plaque to $99.0 \%$. Gundy et al. (2008) who compared the survival of SARS-CoV-1 and poliovirus in water reported that coronaviruses can stay longer in water, except in tap waters at $4^{\circ} \mathrm{C}$.

5. Access to good water supply and sanitation can reduce the occurrence of infectious diseases including COVID-19

A technical guide on the use of water, water sanitation, and management of wastes from health care facilities has been published by the World Health Organization (WHO, 2020c). This is very useful in preventing viral outbreaks including coronaviruses.

6. Household water treatment can remove viruses from water

Household water treatments have been reported to successfully fight against protozoa and bacteria but not for viruses. It is therefore important to select a suitable technology of water treatment in households against viruses such as boiling, chlorination, and ultrafiltration. To this end, the World Health Organization has published two reports (Round I and II) on the various household water treatment procedures and 
their effectiveness in the removal of viruses (WHO, 2020 d,e).

7. The possible presence of COVID-19 virus on the toilet and other surfaces

The toilet areas of hospital and health facilities treating cases of COVID-19 patients have been reported to be the most contaminated areas (Ding et al. 2020). Human coronavirus can be persistent on inanimate surfaces such as metal, glass, or plastics. This statement was substantiated by the reports of Kampf et al. (2020) and revealed that human coronaviruses such as SARS and MERS, or HCoV can persist on metal, glass, or plastic for up to 9 days. Surface disinfection with $62-71 \%$ ethanol, $0.5 \%$ hydrogen peroxide, or $0.1 \%$ sodium hypochlorite was recommended as an effective procedure to inactivate coronaviruses within one minute.

8. The spread of the virus through surfaces can be effectively prevented by regular washing hands with soap

The World Health Organization has published guidelines on hand hygiene in health care situations (WHO, 2020f e). Siddharta et al. (2017) evaluated the recommended 2 alcohol-based formulations used for outbreak-associated infections and reported that Zika virus (ZIKV), Ebola virus (EBOV), SARS, and MERS could be efficiently inactivated. This substantiates the use of alcohol-based formulations in healthcare systems and situations of the viral outbreak.

9. COVID-19 virus spreads through water droplets from coughing, sneezing or contaminated surfaces

During the COVID-19 outbreak in Wuhan city, China, six family members were studied after visitation to a hospital in the city. It was concluded from the findings of the study that person-to-person transmission of the virus is very consistent in hospitals, family settings, and infected travelers from other regions (Chan et al. 2020). The stability of SARS-CoV2 in aerosols and on surfaces such as plastic and copper were evaluated by studies of Van Doremalen et al. (2020). Throughout the 3-hour experiment, the virus was observed to remain viable in aerosols, it was viable up to 72 hours after application on plastic and steel, no viable virus was detected after 4 hours on copper and after 24 hours on cardboard.

10. Presence of infectious COVID-19 virus is very unlikely

Based on the findings that infectious COVID-19 virus could not be extracted from contaminated feces (Wölfel et al., 2020) and its likely inactivation in water within days (Wang et al., 2005), the presence of infectious COVID-19 is therefore very unlikely to be in drinking water intakes.

11. The treatment plant acts as a barrier against the COVID-19 virus and other viruses

COVID-19 is very sensitive to disinfectants when compared with other viruses in water (Wang et al., 2005). The design and technologies of UV irradiation, ozonation and membrane filtration in water treatment plants has made possible the inactivation of the most persistent viruses in water and very effective against the COVID-19 virus.

12. Safely managed tap water is well protected against COVID-19 virus

The World Health Organization has published guidelines, which have eliminated the presence of viruses in drinking water. With these guidelines in place, tap water can be safe from all viruses including the COVID-19 virus and humans, animals and fishes that depend on the water are free from contamination. 


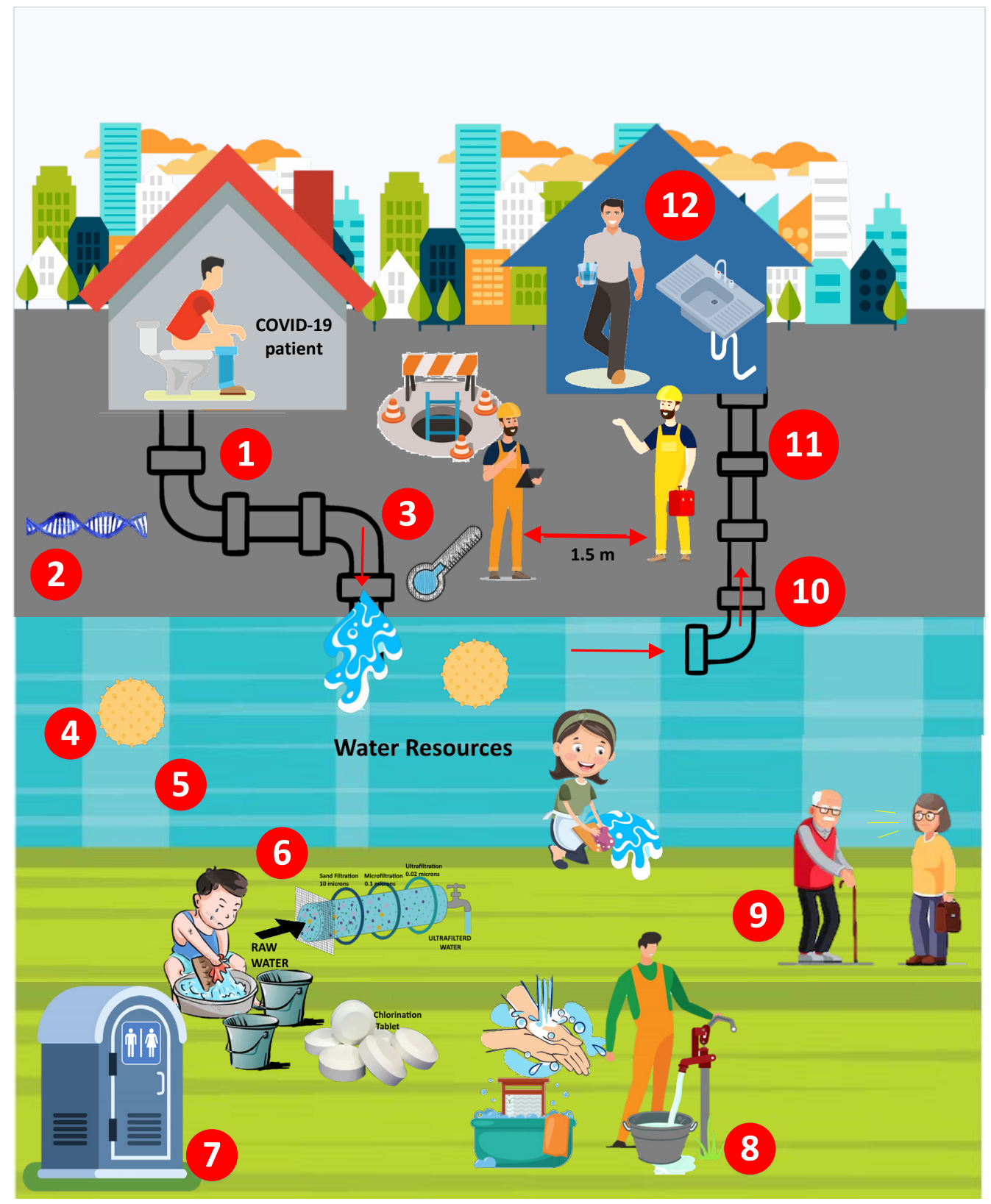

1. Cultivation of COVID-19 virus from stool is difficult

2. Genetic material of COVID-19 virus found in sewage water

3. Poor survival of SARS-CoV-1 (very similar virus to COVID-19) in water $>20^{\circ} \mathrm{C}$ indicates inactivity of COVID-19 virus in water

4. Other viruses, e.g. rotavirus, are more persistent in water than the COVID-19 virus

5. Access to good water supply and sanitation can reduce the occurrence of infectious diseases including COVID-19

6. Household water treatment can remove viruses from water (Chlorination tablets and Ultrafiltration)

7. The possible presence of COVID-19 virus on the toilet and other surfaces

8. The spread of the virus through surfaces can be effectively prevented by regular washing hands with soap

9. COVID-19 virus spreads through water droplets from coughing, sneezing or contaminated surfaces

10. Presence of infectious COVID-19 virus is very unlikely

11. The treatment plant acts as a barrier against the COVID-19 virus and other viruses

12. Safely managed tap water is well protected against COVID-19 virus

Figure 1. 12 facts about COVID-19 in water: The importance of water access and hygiene in times of crisis (modified from Tu Delft, 2020) 


\section{Case Studies on the Presence of Coronavirus in Wastewater}

Scientific researchers have reported the possibility of human infection of viruses from water and wastewaters (Choudri and Charabi, 2019). The virus can remain active for days in sewage and it can be transmitted from wastewater to humans if aerosols are generated (Hung, 2003; Casanova et al. 2009). This was the scenario in the SARS-CoV outbreak in 2003 where wastewater from a residential leaking sewage pipe was aerosolized and caused an outbreak of the virus in Hong Kong (Hung, 2003). This illustrates another way by which the coronavirus can be transmitted to humans' asides the known ways through respiratory droplets and fecal-oral route. The presence of the coronavirus has been reported in a community wastewater system in the USA, Netherlands, and Sweden (Igomu, 2020).

\section{Netherlands}

Traces of SARS-CoV-2 were detected in wastewater by researchers at the Netherlands National Institute for Public Health and the Environment in Bilthoven, Netherlands. The wastewater was generated from the Schiphol Airport in Tilburg four days after the country detected its first case of the virus through clinical testing. Based on these results, researchers have been tasked to sample the 12 provinces in the country and their capitals as well as the 12 areas with no confirmed cases of the virus (Mallapaty, 2020)

\section{France}

The virus was reported to be found in the Paris sewage system after it studied for one month. The results from the study presented a fluctuating pattern in the presence of the virus, which was similar to the pattern observed from the outbreak in the region (Leste-Lasserre, 2020).

\section{Australia}

It took about two months (March - April 2020) for the presence of the virus to be confirmed in wastewater from Brisbane in Australia. The trend observed from wastewater sampled was similar in pattern to the trends detected through direct human testing.

\section{United States of America}

The country has employed the use of wastewater to investigate the presence of the virus. Traces of the virus have been observed by scientists who analyzed the wastewater from an urban water treatment facility in Massachusetts.

\section{Ways of Minimizing Coronavirus in Wastewater}

Disinfection remains a major way of minimizing the virus in water. Based on the widespread of the virus, some procedures have been developed for disinfecting wastewater to inactivate the virus pathogens. In the United States, guidelines for the treatment of wastewater were released in February 2020 by the Occupational Safety and Health Administration (OSHA) to protect the public and aquatic ecosystem from the coronavirus. The procedure involves the processes of oxidation of wastewater with free chlorine and the use of ultraviolet radiation for virus inactivation in wastewater treatment (OSHA, 2020).

\section{Chlorine disinfectants}

The use of chlorine for disinfection remains the best economical solution for inactivation of the virus; although chlorine can combine with the ammonia in the wastewater to form chloramide. It was reported by the China Ministry of Ecology and Environment (2020) that in China where the strain of the virus was discovered has applied chlorine treatment of more than 5000 tons in Wuhan city alone both indoors and outdoors to minimize the effects of the virus. The increased volume of wastewater containing a high concentration of chlorine may find its way into aquatic systems thereby causing secondary infection and threaten the survival of aquatic biodiversity. Zhang et al. (2020b) stated that chlorine toxicity can affect the sustainability of the aquatic system in the following ways:

$i$. They can harm aquatic organisms directly by damaging their cell walls or their protein by oxidation

ii. The chemicals in the disinfectant can bond with other materials and form harmful compounds in water

iii. They can bind with Nitrogen to form Chloramide or $\mathrm{N}$-nitroso-dimethyl amide, which is carcinogens.

$i v$. The synthesis of disinfection byproducts such as trihalomethanes or haloacetic acids which is very toxic to aquatic life can occur in surface waters because of high organic matter

\section{Bleach as disinfectant}

It is a very strong disinfectant which inactivates bacteria, viruses, and fungi. It contains the active ingredient sodium hypochlorite. Based on this, the WHO (2020g) recommended the use of sodium hypochlorite at $0.5 \%$ to clean surfaces. It is readily available and can be used in households or surface cleaning in hospital facilities. Its limitations are that it can irritate the mucous membranes in humans and react easily with other chemicals in the water. It should, therefore, be used as 
stipulated with care and in a well-ventilated place (WHO, 2014)

\section{Alcohol as disinfectant}

It is very flammable and can be used to disinfect small external surfaces such as equipment's. Based on its flammable property, its use must be limited and in a well-ventilated area. If used repeatedly on a particular surface, it may result in thickening, hardening, discoloration or cracking of such surfaces. The use of alcohol ( $70 \%$ ethyl alcohol) is very effective in fighting against the influenza virus (WHO 2014, 2020g).

\section{Possible Solutions for the Sustainability of the Aquatic Environment}

With the increased volume of wastewater generated due to the advent of the virus, a central collection reservoir, which can receive the volume of wastewater from major sources such as the hospitals and health centres, can be created. The reservoir can be likened to a waste stabilization pond that retains the wastewater for a certain period and the pathogens can be destroyed over time. During the wastewater retention period, the intensity of sunlight, $\mathrm{pH}$, and the biological activity in the wastewater speeds up and equates to the rate of destruction of the pathogen (Zhang et al. $2020 \mathrm{c}$ ). A virus inactivation treatment procedure can be employed at the central collection reservoir so that the environmental loading and secondary transmission of the virus can be minimized. It is also important to understand the potency of methods of disinfection employed in coronavirus inactivation ( $\mathrm{Li}$ et al. 2017).

The virus outbreak has resulted in an increased use of disinfectants and bactericides on indoor and outdoor surfaces and in water to limit the spread. In the long run, this act can make abundant the presence of antibiotic-resistant bacteria in the environment and can pose an indirect impact on the aquatic ecosystem and human health.

The use of molecular methods and nucleic acid targets by researchers to investigate the virus can also be carried as stated by the Centres for Disease Control (CDC). This method can be used to detect the presence of the SARS-CoV-2 virus in wastewater samples through the use of genetic markers. This method may be carried out when the wastewater is received and after it has been treated in the facility to check for the presence and level of the virus in wastewater before it is discharged into the environment (Brandt, 2020).

Individuals suspected to have the virus may have isolated toilets or latrines whereby their fecal materials can be collected and the toilets must have lids to prevent wastewater droplets that may spatter or form aerosol clouds. If isolation of latrines is not possible, the general latrines should be constantly disinfected and the plumbing system should be of the standard to prevent leakages or the formation of aerosol clouds which may air ventilation systems thereby spreading the virus as it occurred for SARS-CoV in Hong Kong in 2003 (Yu et al. 2004) and the concerns currently raised about the spread of SARS-CoV-2 from faulty plumbing systems in toilets (Regan, 2020). It is important to observe strict surveillance on sewage disposal systems to assess the effectiveness of the strategies of the disposal system on the disease prevention and control (Brandt, 2020).

\section{Conclusion}

It can be seen that the coronavirus is present in wastewater and humans are prone to infection of the pathogen from this source if aerosol clouds are formed and dispersed in the air. The occurrence of the SARS-CoV and SARS-CoV 2 indicates the persistence and existence of the virus and measures to reduce its effects on the aquatic ecosystem and humans is utmost. The aquatic system is the sink that receives water from various sources and the measures taken on potential water aquifers and wastewater treatment plants will determine the health of the aquatic ecosystem in terms of water quality and sustainability of biodiversity. To this end, aquatic ecological integrity assessment must be integrated into water management measures by countries of the world to constantly check and monitor the state of our aquatic systems. In addition, the creation of central reservoirs and proper plumbing systems to avert leakage and aerosol forming situations can be looked into as a measure for reducing the impacts of wastewater on aquatic ecosystems. With these, humans and all forms of aquatic biodiversity such as fish, crustaceans etc. can be protected from life threats that may originate from polluted waters in the environment.

\section{Compliance with Ethical Standard}

Conflict of interests: The authors declare that for this article they have no actual, potential or perceived conflict of interests.

\section{Ethics committee approval: -}

Funding disclosure: -

Acknowledgments: We thank the anonymous reviewers for their careful reading of our manuscript and their useful comments and suggestions. 


\section{References}

Adhikari, S.P., Meng, S., Wu, Y., Mao, Y., Ye, R., Wang, Q., Sun, C., Sylvia, S., Rozelle, S., Raat, H., Zhou, H. (2020). Epidemiology, causes, clinical manifestation and diagnosis, prevention, and control of coronavirus disease (COVID-19) during the early outbreak period: a scoping review. Infectious Diseases of Poverty, 9, 29.

https://doi.org/10.1186/s40249-020-00646-x

Aquatech (2020, March 17). Coronavirus and water/wastewater: A round-up of global advice.

http://www.aquatechtrade.com/news/article/coronavirusand-water-wastewater-global-advice/ (accessed 16.05.2020).

Casanova, L., Rutala, W.A., Weber, D.J., Sobsey, M.D., (2009). Survival of surrogate coronaviruses in water. Water Research, 43(7), 1893-1898.

https://doi.org/10.1016/j.watres.2009.02.002

Brandt, R., (2020, April 5). The team tracks coronavirus in wastewater. University of Arizona. http://www.futurity.org/coronavirus-in-wastewater-2326802-2/ (accessed 27.04.2020).

Chan, J.F., Yuan, S., Kok, K., To, K.K., Chu, H., Yang, J., Xing, F., Liu, J., Yip, C.C., Poon, R.W., Tsoi, H., Lo, S.K., Chan, K., Poon, V.K., Chan, W., Ip, J.D., Cai, J., Cheng, V.C., Chen, H., Hui, C.K., Yuen, K., (2020). A familial cluster of pneumonia associated with the 2019 novel coronavirus indicating person-to-person transmission: a study of a family cluster. Lancet, 395, 514-523.

https://doi.org/10.1016/S0140-6736(20)30154-9

Chattopadhyay, S., Taft, S. (2018, August 1). Exposure Pathways to High- Consequence Pathogens in the Wastewater Collection and Treatment Systems, U.S. Environmental Protection Agency, Cincinnati, OH. EPA/600/R18/221, 2018.

https://cfpub.epa.gov/si/si public record report.cfm?Lab=NHSRC\&dirEntryId $=341856$ 27.04.2020)

China Ministry of Ecology and Environment (2020, April 21). Will viruses and disinfection affect water quality? The ministry of ecology and Environment responded. http://www.mee.gov.cn/ywgz/ssthjbh/dbssthjgl/202003/t20 200311 768408.shtml (in Chinese) (accessed 27.05.2020).

China Ministry of Ecology and Environment (2020, April 21). Will viruses and disinfection affect water quality? The ministry of ecology and Environment responded. http://www.mee.gov.cn/ywgz/ssthjbh/dbssthjgl/202003/t20 200311 768408.shtml (in Chinese) (accessed 27.05.2020).

Choudri, B.S., Charabi, Y. (2019). Health effects associated with wastewater treatment, reuse, and disposal. Water Environment Research, 91, 976-983.

https://doi.org/10.1002/wer.1157

Ding, Z., Qian, H., Xu, B., Huang, Y., Miao, T., Yen, H., Xiao, S., Cui, L., Wu, X., Shao, W., Song, Y., Sha, L., Zhou, L., Xu, Y., Zhu, B., Li, Y., (2020). Toilets dominate environmental detection of SARS-CoV-2 virus in a hospital. medRxiv,

https://doi.org/10.1101/2020.04.03.20052175

Goldstein, J. (2020, April 6). Bronx Zoo Tiger is sick with the coronavirus. The New York Times. https://www.nytimes.com/2020/04/06/nyregion/bronx-zoo-tiger-coronavirus.html (accessed 16.04.2020).

Gundy, P.M., Gerba, C.P., Pepper, I.L., (2009). Survival of Coronaviruses in Water and Wastewater. Food Environmental Virology, 1, 10-14.

https://doi.org/10.1007/s12560-008-9001-6

Hoffman, M., Kliene-Weber, H., Kruger, N., Herrler, T., Erichsen, S., Schiergens, T.S., Herrler, G., Wu, N.-H., Nitsche, A. Müller, M.A. Drosten, C., Pöhlmann, S. (2020). SARS-CoC-2 cell entry depends on ACE2 and TMPRSS@ and is blocked by a clinically proven protease inhibitor. Cell, 181(2), 271-280.

https://doi.org/10.1016/j.cell.2020.02.052

Holshue, M.L., DeBolt, C., Lindquist, S., Lofy, K.H., Wiesman, J., Bruce, H., Spitters, C., Ericson, K., Wilkerson, S., Tural, A., Diaz, G., Cohn, A. et al. (2020). First case of 2019 novel coronavirus in the United States. The New England Journal of Medicine, 382(10), 929-936.

https://doi.org/10.1056/NEJMoa2001191

Hung, L.S. (2003). The SARS epidemic in Hong Kong: what lessons have we learned?, Journal of the Royal Society of Medicine, 96, 374-378.

https://doi.org/10.1177/014107680309600803

Ignatus, T.S., Yu, M.B., Yugho, L., Wong, T.W., Tam, W., Chan, A.T., Lee, J.H.W., Leung, D.Y.C., Ho, T. (2004). 
Evidence of air-borne transmission of the severe acute respiratory syndrome virus. The New England Journal of Medicine, 350(17), 1731-1739.

https://doi.org/10.1056/NEJMoa032867

Igomu, T. (2020, April, 12). Health: wastewater flowing in communities can reveal the presence of COVID-19- Scientists. Punch Newspaper.

https://healthwise.punchng.com/waste-water-flowing-incommunities-can-reveal-presence-of-covid-19-scientists/ (accessed 16.04.2020).

Kampf, G., Todt, D., Pfaender, S., Steinmann, E. (2020). Persistence of coronaviruses on inanimate surfaces and their inactivation with biocidal agents. Journal of Hospital Infection, 104(2020), 246-251.

https://doi.org/10.1016/j.jhin.2020.01.022

Leste-Lasserre, C. (2020). Coronavirus found in Paris sewage points to early warning system. Science, 368, 6489. https://doi.org/10.1126/science.abc3799

Letko, M., Marzi, A., Munster, V. (2020). Functional assessment of cell entry and receptor usage for SARS-CoV-2 and other lineage beta coronaviruses. Nature Microbiology, 5(4), 562-569.

https://doi.org/10.1038/s41564-020-0688-y

Leung, W.K., To, K.F., Chan, P.K.S., Chan, H.L.Y., Wu, A.K.L., Lee, N., Yuen, K.Y., Sung, J.J.Y. (2003). Enteric involvement of severe acute respiratory syndrome-associated coronavirus infection, Gastroenterology, 125, 1011-1017. https://doi.org/10.1016/S0016-5085(03)01215-0

Li, W., Jain, T., Ishida, K., Liu, H. (2017). A mechanistic understanding of the degradation of trace organic contaminants by UV/hydrogen peroxide, UV/persulfate, and UV/free chlorine for water reuse. Environmental Science: Water Research \& Technology, 3, 128-138.

https://doi.org/10.1039/C6EW00242K

Mallapaty, S. (2020). How sewage could reveal the true scale of the coronavirus outbreak. Nature, 580, 176-177. https://doi.org/10.1038/d41586-020-00973-x

Medema, G., Heijnen, L., Elsinga, G., Italiaander, R., Brouwer, A., (2020). Presence of SARS-Coronavirus-2 in sewage. medRxiv,

https://doi.org/10.1101/2020.03.29.20045880
Naddeo, V., Liu, H. (2020). Editorial Perspectives: 2019 novel coronavirus (SARS-CoV-2): what is its fate in the urban water cycle and how can the water research community respond? Environmental Science: Water Research \& Technology, 6, 1213.

https://doi.org/10.1039/d0ew90015j

OSHA (2020). Standards and directives for COVID-19, United States of America Occupational Safety and Health Administration, $\quad$ https://www.osha.gov/SLTC/covid19/standards.html (accessed 17.05.2020)

Pieres, J.S.M. Chu, C., Cheng, V.C.C., Chan, K.S., Hung, I.F.N., Poon, L.L.M., et al. (2003). Clinical progression and viral load in a community outbreak of corona virus-associated SARS pneumonia: A prospective study. The Lancet, 361, 1761-1772.

https://doi.org/10.1016/S0140-6736(03)13412-5

Raphael, R.A., Sattar, S.A., Springthorpe, V.S., (1985). Long-term survival of human rotavirus in raw and treated river water. Canadian Journal of Microbiology, 31(2), 124128.

https://doi.org/10.1139/m85-024

Regan, H., (2020, February 12). How can the coronavirus spread through bathroom pipes? Experts are investigating in Hong Kong. https://edition.cnn.com/2020/02/12/asia/hongkong-coronavirus-pipes-intl-hnk/index.html

(accessed 25.04.2020).

Rismanbaf, A., Zarei, S. (2020). Liver and kidney injuries in COVID-19 and their effects on drug therapy; a letter to the editor. Archives of Academic Emergency Medicine, 8(1), $17 \mathrm{e}$.

Sanders, J., (2020, February 29). Chlorine toxicity in fish. Aquatic veterinary services.

https://cafishvet.com/2020/02/29/chlorine-toxicity-in-fish/ (accessed 26.04.2020).

Siddharta, A., Pfaender, S., Vielle, N.J., Dijkman, R., Friesland, M., Becker, B., Yang, J., Engelmann, M., Todt, D., Windisch, M.P., Brill, F.H., Steinmann, J., Steinmann, J., Becker, S., Alves, M.P., Pietschmann, T., Eickmann, M., Thiel, V., Steinmann, E. (2017). Virucidal activity of World Health Organization-recommended formulations against enveloped viruses, including zika, ebola, and emerging coronaviruses. The Journal of Infectious Diseases, 215(6), 902-906.

https://doi.org/10.1093/infdis/jix046 
Tu Delft, (2020, May 12). Tu Delft Global Drinking Water. https://d1rkab7tlqy5f1.cloudfront.net/Websections/Global\%20Drinking\%20Water/Colofon\%20COVID-19\%20virus $\% 20 \mathrm{in} \% 20$ water.pdf (accessed 18.05.2020).

Van Doremalen, N., Bushmaker, T., Hamilton, E.S., Morris, D.H., Holbrook, M.G., Gamble, A., Williamson, B.N., Tamin, A., Harcourt, J.L., Thornburg, N.J., Gerber, S.I., Lloyd-Smith, J.O., De Wit, E., Munster, V.J. (2020). Aerosol and surface stability of SARS-CoV-2 as compared with SARS-CoV-1. The New England Journal of Medicine, 382, 1564-1567.

https://doi.org/10.1056/NEJMc2004973

Wang, X.W., Li, J.S., Jin, M., Zhen, B., Kong, Q.X., Song, N., Xiao, W.J., Yin, J., Wei, W., Wang, G.J., Si, B.Y., Guo, B.Z., Liu, C., Ou, G.R., Wang, M.N., Fang, T.Y., Chao, F.H., Li, J, W. (2005). Study on the resistance of severe acute respiratory syndrome-associated coronavirus. Journal of Virological Methods, 126(1-2), 171-177.

https://doi.org/10.1016/j.jviromet.2005.02.005

WHO (2014, March 11). Infection Prevention and Control of Epidemic- and Pandemic-Prone Acute Respiratory Infections in Health Care. Geneva: World Health Organization; Annex G, Use of disinfectants: alcohol and bleach. https://www.ncbi.nlm.nih.gov/books/NBK214356/

(accessed 22.04.2020).

WHO (2020a, January 17). Novel Coronavirus-Japan (ExChina).

https://www.who.int/csr/don/17-january-2020-novel-coronavirus-japan-ex-china/en/ (accessed 21.04.2020).

WHO (2020b, May 18). World Coronavirus Disease (COVID-19) Dashboard.

https://covid19. who.int/?gclid=CjwKCAjwwYP2BRBGEiwAkoBpApqSYnC 7CfA-c2jptAfCg38TEzlK-

BiY2Z1 GLcxi aIpJdUm7L-qBoC-dUQAvD BwE

(accessed 18.05.2020).

WHO (2020c, April 23). Water, sanitation, hygiene, and waste management for the COVID-19 virus: interim guidance. COVID-19: Infection prevention and control / WASH Published on 23 April, 2020. WHO REFERENCE NUMBER: WHO/2019-nCoV/IPC WASH/2020.3.

https://www.who.int/publications-detail/water-sanitationhygiene-and-waste-management-for-covid-19

(accessed 18.05.2020).
WHO (2020d, March 9). Guidelines for Drinking - Water Quality: Fourth edition incorporating the first addendum. https://apps.who.int/iris/bitstream/handle/10665/254637/9\%20789241549950-eng.pdf;jsessionid=1C04AABC036E337664A11D4E18A9FEFA?sequence $=1$ (accessed 18.05.2020).

WHO (2020e, January 9). Results of Round II of the WHO Household Water Treatment Evaluation Scheme. Published December, 2019.

https://www.who.int/water_sanitation_health/publications/results-round-2-scheme-to-evaluate-houshold-watertreatment-tech/en/ (accessed 18.05.2020).

WHO (2020f, May 5). Hand Hygiene: Why, How \& When? https://www.who.int/gpsc/5may/Hand_Hygiene Why How and When Brochure.pdf (accessed 18.05.2020).

WHO (2020g, March 3). Water, sanitation, hygiene and waste management for the COVID-19 virus. Technical brief by the World Health Organization. WHO reference number: WHO/2019-nCoV/IPC_WASH/2020.1

https://www.who.int/publications/i/item/water-sanitationhygiene-and-waste-management-for-the-covid-19-virus-interim-guidance (accessed 18.05.2020).

Wigginton, K.R., Ye, Y., Ellenberg, R.M. (2015). Emerging investigators series: the source and fate of pandemic viruses in the urban water cycle. Environmental Science: Water Research \& Technology, 1(6), 735-746.

https://doi.org/10.1039/C5EW00125K

Wölfel, R., Corman, V.M., Guggemos, W., Seilmaier, M., Zange, S., Müller, M.A., Niemayer, D., Jones, T.C. Vollmar, P., Rothe, C., Hoelscher, M., Bleicker, T., Brünink, S., Schneider, J., Ehmann, R., Zwirglmaier, K., Drosten, C., Wendtner, C. (2020). Virological assessment of hospitalized patients with COVID-2019. Nature, 581, 465469.

https://doi.org/10.1038/s41586-020-2196-x

Xu Z, Shi L, Wang Y, Zhang J, Huang L, Zhang C, Liu, S., Zhao, P., Liu, H., Zhu, L., Tai, Y., Bai, C., Gao, T., Song, J., Xia, P., Dong, J., Zhao, J., Wang, F.-S. (2020). Pathological findings of COVID-19 associated with acute respiratory distress syndrome. The Lancet Respiratory Medicine, 8(4), 420-422.

https://doi.org/10.1016/S2213-2600(20)30076-X 
Zhang, H., Kang, Z., Gong, H., Xu, D., Wang, J., Li, Z., Cui, X., Xiao, J., Meng, T., Zhou, W., Liu, J., Xu, H. (2020a). The digestive system is a potential route of 2019nCov infection: a bioinformatics analysis based on singlecell transcriptomes. bioRxiv.

https://doi.org/10.1101/2020.01.30.927806

Zhang, H., Tang, W., Chen, Y., Yin, W. (2020b). Disinfection threatens aquatic ecosystems. Science, 368(6487), 146147. https://doi.org/10.1126/science.abb8905

Zhang, Y., Chen, C., Zhu, C., Wang, D., Song, J., Song, Y., Zhen, W., Feng, Z., Wu, G., Xu, J., and Xu, W. (2020c). Isolation of 2019-nCoV from a stool specimen of a laboratory-confirmed case of the coronavirus disease 2019 (COVID-19). China CDC Weekly, 2(8), 123-124 (In Chinese).

https://doi.org/10.46234/ccdcw2020.033 